\title{
Indonesian Consumers' Attitudes towards Organic Products
}

\author{
Budi Suharjo 1,*, Muchlis Ahmady², Mohammad Reza Ahmady ${ }^{3}$ \\ ${ }^{1}$ Department of Mathematics and Graduate School of Management and Business, Bogor Agricultural University, Indonesia \\ ${ }^{2}$ Alumni of Graduate Program of Management and Business, Bogor Agricultural University, Indonesia \\ ${ }^{3}$ Alumni of MA Marketing Management, Middlesex University, United Kingdom
}

Copyright $\bigcirc 2016$ by authors, all rights reserved. Authors agree that this article remains permanently open access under the terms of the Creative Commons Attribution License 4.0 International License

\begin{abstract}
The increased public awareness of health in recent decades was expected to have positive impact on the increase in demand for organic food products. It is because these products are produced using natural farming system, which produces healthier and safer foods for consumption. But over time, the number of consumers of organic products in Indonesia tends to stagnate. This means that the initial assumption stating that there would be growing demand for organic products was not fully proven. Many researchers have revealed these conditions, where price is one of the crucial factors that inhibit the acquisition. This research aims to uncover other factors that influence consumers' attitudes towards organic food products, as well as to discover the price level at which people are starting to willingly buy the products. This research was conducted in several shopping malls located in Jakarta and Bogor (West Java) from February 2012 - March 2012, covering 200 respondents who were surveyed by accidental sampling technique. The low growth of consumers for organic food products in Indonesia is caused partly by the still minimal information about the benefits of organic food products. Most people have the perception that the benefits of organic products are not different from non-organic food products and organic products are not durable. Physically, it is difficult to distinguish between organic products and non-organic products. Those who had consumed them stated that the benefits of organic products could not be perceived directly. People who are interested to consume them regularly experience difficulties in getting the products because the products are only sold in certain places, and they are not even always available at any given time. In addition, high prices become obstacles for those who are willing to consume regularly. In addition, high prices become obstacles for those who are willing to consume regularly. The price difference of up to $5 \%$ compared to conventional products is the price level considered reasonable by all consumers. While the difference up to $10 \%$, then $80 \%$ of consumers are still willing to buy. But if the price is more expensive by $20 \%$, only $50 \%$ of consumers who can afford to buy.
\end{abstract}

Keywords Organic Product, Awareness, Availability, Price Difference

\section{Introduction}

Researches related to organic products have been carried out by many researchers with different scientific backgrounds. [28] Has conducted a review of various literature related to the topic. In general, [28] has concluded that there have been inconsistencies associated with the high interest of the public to consume organic products, but in fact only a few consumers fulfil that desire. This is caused by many things; among these factors are price, product availability, individual factors, and consumption habits. One of the suggestions of the results of literature reviews is to reveal the inconsistencies linking to socio-cultural and demographic aspects.

Since the last few decades, public awareness of health and preservation of global environment has had an impact on people's behavior to consume healthy foods produced without damaging the environment [18]. It is inseparable from the role of government and relevant institutions in campaigning for environmental conservation and healthy lifestyles [14,21]. This situation is addressed by farmers and entrepreneurs in the field of agriculture by producing organic foods without damaging the environment, namely air, water and soil, so that their products are healthy and safe for consumption. Organic foods have become a trend in almost all over the world. [22] defines organic foods as "foods derived from organic farming systems that implement practical management with the aim of preserving the ecosystem to achieve sustainable production, as well as weed, pest and disease control through various means, such as recycling crop and livestock residues, crop selection and rotation, irrigation management, cultivation and planting along with the use of biological materials."

The population of Indonesia until the end of 2015 was expected to reach 250 million people [9], in which $38 \%$ of them worked in the agricultural sector. The growth of the socio-economically middle class group, as a reflection of the growing prosperity of the community, was accompanied by the growing level of health awareness. This was a positive signal of the increasing preference towards healthy and safe food products. This was similar to what had been revealed by [24] as well as [25]; increasing public awareness of health 
would increase the desire of people to consume organic food products. The situation was responded positively by businesses in the agricultural sector and was also encouraged by the government to boost agricultural production cultivated with organic farming systems [16].

However, the initial allegation of the rapid demand for organic food products was not proven factually; the growth in the number of consumers of organic products is still low. This situation is in line with the results of research by [17] and previously has also been expressed by [24] and [23]. From the number of people who originally had the desire to consume organic products, only a small part of the group fulfils that desire.

[16] has reported that in 2007 the total area of organic farming in Indonesia reached 40,970 Ha. Up to the period of 2011 , organic agricultural areas increased sharply to 238,873 Ha. But until the end of 2013, there was a decrease in the extent of land down to 225,063 $\mathrm{Ha}$, and this downward trend continued to the end of 2015. The decrease was due to the fact that farmers no longer continued the certification of agricultural products. This was caused by the low growth of consumers' demand for organic food products or the unstable volume of organic products. As a result, some organic farmers have switched back to non-organic farming, because it is more profitable [16]. [15] has reported that, in 2006 , the area of organic farming in Indonesia was only about $0.09 \%$ compared to the area of agriculture as a whole.

The factors causing the slow growth of organic foods' consumers have been described by [20], in that most of the consumers said that they choose organics products because of their environmentally friendly nature, but they do not make actual allocation of dollars in purchases. Although there have been many results of new inventions stating that organic foods have the qualities that give positive effects on health, consumers are still not sure that the products are better, more secure, and more nourishing [27]. They do not see any direct personal advantages because the products are considered very expensive. There are two important issues associated with the condition. First, green products must function effectively [20]. The second is in accordance with what has been expressed by [3], which is consumers are ready to buy green products more often, but prices and quality are still the more important aspects to be consider. Therefore, green products must perform competitively just like traditional products. It has also been expressed by [5] that most people have considered that the prices of green products are higher than others, even though they are ready to buy these green products. On the other side, [11] has reported that the general perception of green products is negatively related to customers' intent to purchase; this is caused by the belief that the prices of organic products are higher, but the quality is not necessarily better than conventional products. According to [25], lack of demand on organic foods in Indonesia is due to the unreliable market, in which people do not pay attention or even realize about organic foods and their benefits.

Based on the above, the main purpose of this research is to determine the factors that influence consumers' attitudes towards organic products in Indonesia and determine the price ranges of organic products, which can still be acceptable to consumers associated with demographic aspects.

\section{Organic Products}

Healthy lifestyle through back to nature has become a new trend for some people. Currently, organic foods attract the attention of these people. Although the prices are relatively more expensive, they are comparable to the benefits obtained. In addition, new facts have shown that organic foods contain more nutrients. People have begun to abandon their lifestyle of foods with high fat content and calories and low in fiber. This is a positive phenomenon that needs to be deployed, because only a small group of people realizes the healthy lifestyle. Good knowledge and awareness are needed to change people's lifestyle [27].

[8] has reported that, although the number of people who want to purchase green products has increased in recent years, there is little evidence to suggest that the purchase of green products has been increasing. It is no doubt that the environmental awareness and positive attitude of consumers towards sustainability and green products are growing. Ironically, the market share of green products is only about $1-3 \%$ of the entire market. This suggests that consumers' consideration on environmental sustainability in making purchasing decisions is still low. This means that people generally ignore the environmental impact of their purchases [19].

Some of the factors that hinder the development of organic products and their distribution in Indonesia are the availability issue of organic products, the perception of organic products, and the high prices compared with conventional food ingredients [6].

In addition, consumers' lack of awareness and knowledge of organic products and the limited purchasing power of most people are major barriers for the Indonesian people to consume organic products [25]. According to [14], there are two major challenges faced by companies in order to successfully promote organic food products. The first is consumers' doubt in differentiating which products are organic and which are not. The second is ensuring the benefits of organic products; why they are more expensive than conventional products. Therefore, trust becomes one aspect of the motivation that encourages consumers to willingly buy the products, or vice versa, it can be a barrier for consumers to buy organic products [27]. When they were asked why they did not buy organic food products, they answered that they did not believe the organic label attached to the products. They did not believe and assumed there had been frauds; farmers had been deceptive or traders had cheated. Many organic farmers were considered to have abandoned their ideals and becoming more profit oriented, thus they have forged organic label on products that are not actually organic. As a matter of fact, organic farming has 
grown and has rooted idealism to create a balanced environment due to the use of chemicals as low as possible, so everything is done with honesty [2].

Because of that constrains, Bogor Institute of Agriculture as the biggest agricultural institute in Indonesia has encouraged themselves to call upon the farmers to cultivate organically with guaranteed results where the production is accommodated by the Institute. To give added value in organic products produced, Bogor Institute of Agriculture operates high quality control and creates interesting packages. Bogor Institute of Agriculture distributes the products by open franchise around West Java, but sales currently are still very lacking compared to people's consumption in conventional foods. With Indonesia's population of over 215 million people, which is still growing, there is no doubt that organic agricultural products will have a market in the future in Indonesia. According to the owner of a general supermarket, there are currently approximately 15 million people in Indonesia consuming organic foods [6]. Although the trade of organic products is mushrooming in big cities, there are only very few shops specializing in organic products.

\section{Research Methodology}

We used exploratory and quantitative research methods to collect primary and secondary data. The first step was using literature to get the concept of thinking about the research. The second step was conducting in-depth interviews with key informants to obtain in-depth information related to the research topic. The third step was conducting field observation to support the making of the questionnaire. The fourth step was conducting face to face interviews with 200 respondents in the shopping centers by using accidental sampling method. After the data had been collected, it was then processed and analyzed using SPSS software for Windows. Data analysis was essentially a series of structured activities aimed at exploring the hidden information from the data using statistical norms. This information included the characteristics of the population represented by the samples as well as the patterns of linkages between these characteristics.

Related to the research objectives, the methods of analysis used in this study included descriptive analysis and quantitative analysis. Descriptive analysis aimed to summarize the data in tabular or graphical form. Through this method, the data was expected to show the results in a simple and easy way to understand. Quantitative data analysis was used to explore the relationship between the characteristics of the data. Some quantitative analysis methods used included Chi-Square Test, and Correspondence Analysis.

\section{- Chi-Square Test}

This analysis is basically used to determine whether there is a connection between categories of contingency tables. The application of this analysis can also be used to see the correlation between categories through its contingency coefficient [1].

\section{- Correspondence Analysis}

This analysis is part of multivariate data analysis, which aims to examine the relationship between the categories of the data, where the results of the analysis are presented in the form of two-dimensional diagram. Correspondence analysis is a further analysis of the Chi-Square test to see the pattern of linkages between characteristics (category) of contingency tables [4].

\section{Research Results and Analysis on Findings}

\subsection{Demographic Profile}

Respondents, 200 people in total, were recruited in middle-class shopping malls, which were visited by people from middle-high economic classes, with the average level of household consumption expenditure was minimum IDR 3 million per month. The demographic profiles of respondents were $80 \%$ aged between $25-44$ years, while the majority (28\%) was in the age range of 35-39 years. In terms of spending levels for household consumption, $49 \%$ were in the range of IDR $2.5-<3.5$ million (SEC B), IDR 2.5 to 3.5 million; SEC $(\mathrm{B}+), 43 \%$ were in the range of IDR 3.50-6.0 million (SEC A), while 10\% spend more than IDR 6 million (SEC A+). The majority of respondents (34\%) worked as staffs and middle management in private companies, $26 \%$ were housewives, while others were scattered in various professions. Respondents who were married were amounted to $85 \%$, whereas $12 \%$ were single and the rest were widows or widowers.

\subsection{Knowledge of Organic Food Products}

In regards to organic food products, $93 \%$ of respondents had heard or known the term organic products. Information obtained on this subject was mainly from television $(70 \%)$ as well as printed media, such as magazines $(54 \%)$ and newspapers (49\%), and from family or relatives (35\%). Although TV and printed media still dominated the source of initial information, the information gained from then was still general. On the other hand, the information from family or relatives was generally more detailed because of the interaction between the source and the receiver of the information.

From the survey results, it was revealed that the term organic food products was perceived as healthy products $(51.6 \%)$, due to cropping farming without chemical fertilizers $(26.3 \%)$, not using insecticides in crop pest eradication $(48.4 \%)$, and processing without preservatives $(59.7 \%)$. The results showed that respondents' associated knowledge of organic food products was more directed at production and processing, while the security aspect of the environment as plant growth media and the growth of 
organic products were not mentioned at all. Besides, organic food products were also perceived as expensive products by $23.7 \%$ of respondents.

\subsection{Consumption of Organic Food Products}

From the aspect of the consumption of organic food products, from 186 respondents who had heard or known about organic food products, only $13 \%$ consumed organic food products on a regular basis, $62 \%$ consumed only occasionally, while $25 \%$ had never consumed.

It was of interest to find out the information whether the pattern or intensity of respondents' consumption was linked to demographic aspects, such as household expenditure, age, education level and gender. To find this information, Chi Square Test was performed with the hypothesis being tested that there was no link between the consumption patterns of each of the aspects of demography.

Table 1. Chi-Square test between consumption intensity and demographic aspects

\begin{tabular}{|c|c|c|c|}
\hline Category & Value & Df & P-Value \\
\hline $\begin{array}{c}\text { Consumption Intensity vs. Household } \\
\text { Expenditure }\end{array}$ & 11.701 & 6 & $0.069^{*}$ \\
\hline Consumption Intensity vs. Age Level & 20.207 & 14 & 0.124 \\
\hline $\begin{array}{c}\text { Consumption Intensity vs. Education } \\
\text { Level }\end{array}$ & 11.471 & 6 & $0.075^{*}$ \\
\hline Consumption Intensity vs. Gender & 2.002 & 2 & 0.368 \\
\hline
\end{tabular}

*Significant at level $10 \%$

Table 1 shows that both household spending and the levels of education have a significant relationship with the intensity of the consumption of organic food products. Conversely, gender and age do not have a significant relationship with the intensity of the consumption of organic products. This result can be explained by the fact that in Indonesia education levels and household expenditure are two aspects that can be used to identify groups of people who have the potential to consume organic food products. It is generally known that between the levels of education and levels of spending is a positive relationship; the higher the level of education is, generally the higher the level of spending is. Total expenditure of households or individuals is an approach to their income levels. There is no significant association between gender and age and the intensity of consumption; it can be interpreted that males and females from any age groups have the same opportunities to consume or not consume organic products.

The low numbers of consumers who consumed organic products in regular basis was expected to be associated with income levels. To understand this in detail, the information on the linkages between the levels of expenditure of respondents as an approximation of the income levels was necessary to know. Correspondence analysis was used to determine the detailed patterns of linkages between these two aspects and the results are presented in Figure 1. Consumers with high income level $(\mathrm{A}+)$ regularly consume organic products, while consumers with category A have rather rare or occasional consumption intensity, and consumers with category $\mathrm{B}$ or $\mathrm{B}+$ have never consumed the products. To know the same thing between the levels of education and the patterns of consumption intensity, the same analysis was performed, and the results are presented in Figure 2. Consumers with graduate and post graduate education levels have a higher tendency in consumption compared to other educational levels. This information can be interpreted that the higher the education level of a person is, the higher their awareness of healthy food consumption is. However, people with high level of education cannot be translated directly as a potential market for organic food products, because it is related to income levels.

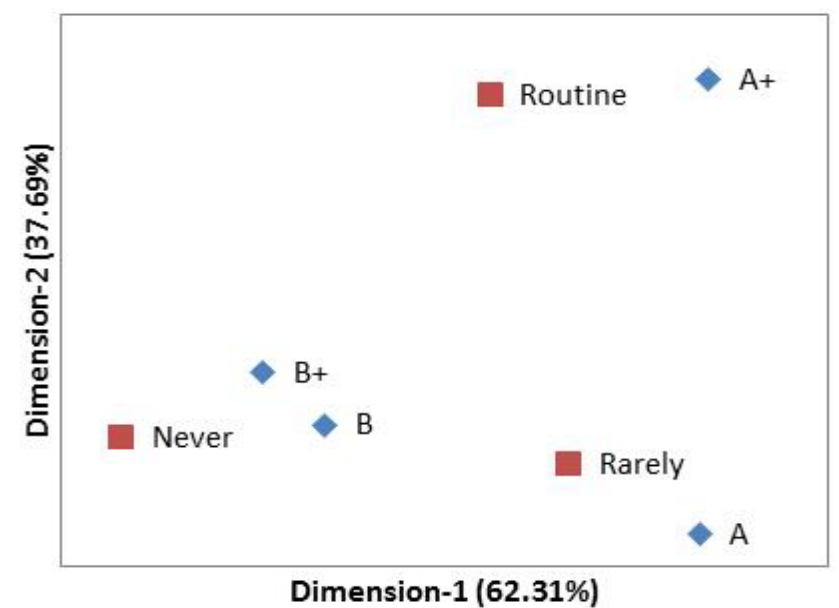

Figure 1. Consumption intensity vs. SEC

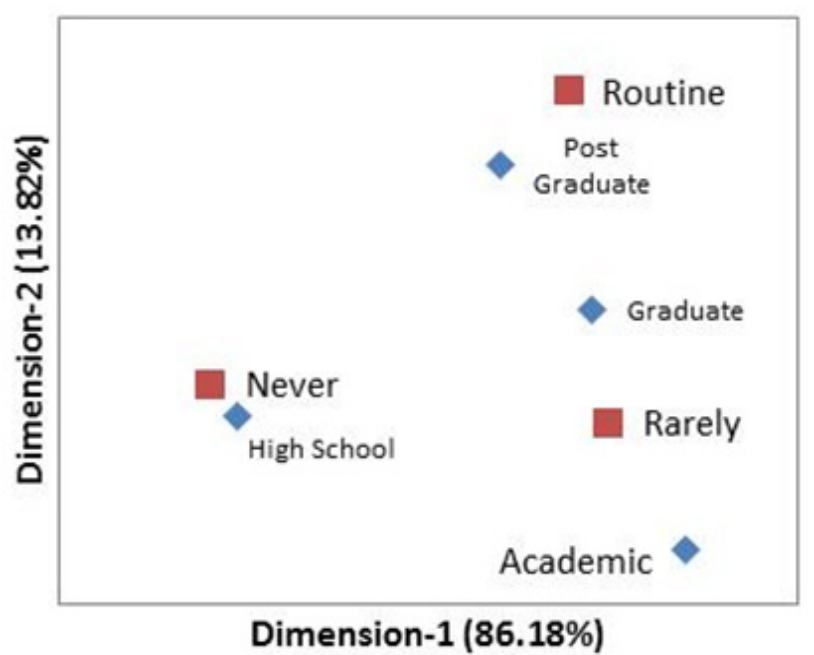

Figure 2. Consumption intensity vs. education level

The types of organic food products consumed by the respondents as well as the percentage of respondents who consume them are presented in Table 2. Organic vegetables, rice and fruits are the kinds of organic food products mostly consumed. These three types of products are currently cultivated by farmers, either individually or in groups, as well as chicken eggs that are the result of organic agricultural products. Meanwhile, the number of respondents who eats 
chicken filets and spices is relatively low.

Table 2. Consumed organic food products

\begin{tabular}{|c|c|}
\hline Type of Organic Food Product & Percentage \\
\hline Vegetables & $70 \%$ \\
\hline Rice & $60 \%$ \\
\hline Fruits & $43 \%$ \\
\hline Eggs & $20 \%$ \\
\hline Spices & $6 \%$ \\
\hline Chickens & $6 \%$ \\
\hline
\end{tabular}

Table 3. Consumption intensity and types of organic products

\begin{tabular}{|c|c|c|c|c|c|c|}
\hline Intensity & Vegetables & Fruits & Rice & Spices & Chickens & Eggs \\
\hline Daily & 8 & 4 & 16 & 4 & 1 & 4 \\
\hline $\begin{array}{c}3-4 \\
\text { times/week }\end{array}$ & 14 & 7 & 5 & 0 & 1 & 3 \\
\hline Once/week & 18 & 12 & 13 & 2 & 1 & 6 \\
\hline Twice/month & 10 & 8 & 8 & 0 & 1 & 2 \\
\hline Once/month & 22 & 20 & 24 & 1 & 1 & 10 \\
\hline Irregular & 25 & 9 & 17 & 1 & 3 & 2 \\
\hline Total & 97 & 60 & 83 & 8 & 8 & 27 \\
\hline
\end{tabular}

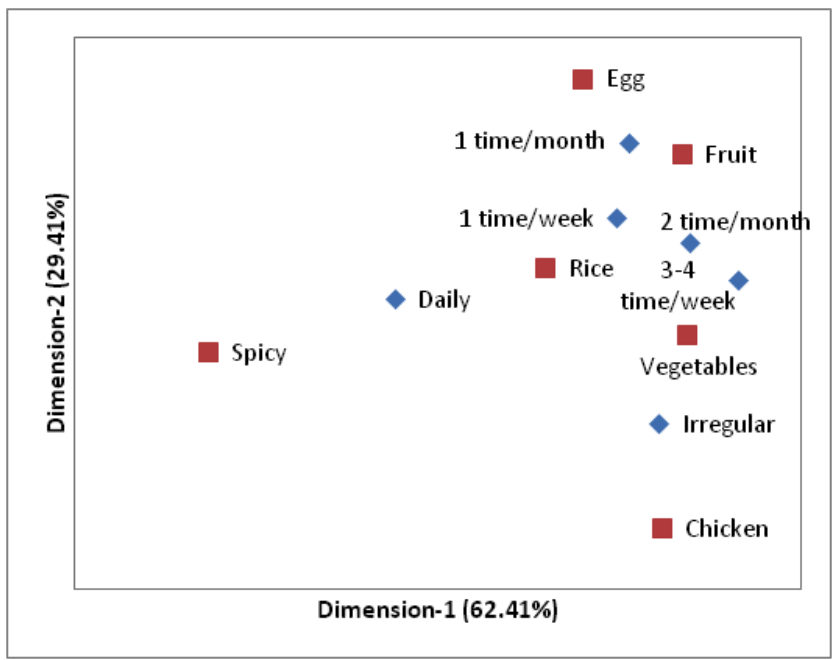

Figure 3. Types of Organic Food Products and Consumption Intensity

From Figure 3, it appears that there is a small group of consumers who regularly consume organic food products. In fact, there is a tendency that the patterns of their consumption of these products are just a distraction. There are only two types of products that have a tendency to be consumed per day, namely rice and spices. This is due to spices as the seasonings for food flavoring that are used every day and are usually not in large numbers, whereas rice is the staple food of Indonesian people.

\subsection{Important factors for consumers in choosing Organic Food Products}

Factors underlying consumers' willingness to consume organic products are important information to know. As seen in Table 4, there are five main reasons for choosing organic foods, namely organic foods are healthy, provide a sense of security because the products are free from harmful chemical substances, are more nutritious, are more hygienic, and taste better.

Table 4. The reasons consumers eat organic food products

\begin{tabular}{|c|c|c|}
\hline Important Factor & Respondent & Percentage \\
\hline Healthy & 117 & $85 \%$ \\
\hline $\begin{array}{c}\text { Feel safe because they are free from harmful } \\
\text { chemicals }\end{array}$ & 99 & $72 \%$ \\
\hline More nutritious & 96 & $70 \%$ \\
\hline More hygienic & 59 & $43 \%$ \\
\hline Taste better & 37 & $27 \%$ \\
\hline
\end{tabular}

\subsection{Problems in Consuming Organic Food Products}

From the results of research conducted by Wijayanto and Miauchi (2002), it has been found that the constraint faced by consumers in the consumption of organic products is a matter of product availability. In this study, 39\% of respondents in this study stated the same thing. Meanwhile, $64 \%$ of respondents could not get organic products because they were only sold at certain places. Another obstacle faced by consumers of organic products is the price factor, which was felt too expensive (49\%). This factor was originally thought to be a major obstacle for people with certain income groups to consume on a regular basis, but the results of Chi-Square analysis to prove the existence of an association between both conditions were not supported by the data. This means that respondents' routine organic food consumption is not determined by income level. It should also be noted that $21 \%$ of respondents did not have significant problems in consuming organic products.

Table 5. Problems encountered by consumers in consuming organic products

\begin{tabular}{|c|c|c|}
\hline Problems encountered & Respondent & Percentage \\
\hline Just sold a special place & 89 & $64 \%$ \\
\hline More expensive & 67 & $49 \%$ \\
\hline Products are not always available & 54 & $39 \%$ \\
\hline No barriers/obstacles & 29 & $21 \%$ \\
\hline $\begin{array}{c}\text { Perishable products (rapid expiration) } \\
\text { Difficult to distinguish with non-organic } \\
\text { products }\end{array}$ & 19 & $14 \%$ \\
\hline Total & 138 & $12 \%$ \\
\hline
\end{tabular}

Claims made by consumers of organic products stated that after they had consumed the products for a certain period of time, they had healthier lives; it was declared by at least $74 \%$ of the respondents. But unfortunately, $25 \%$ of respondents considered that the benefits of organic products were no different than non-organic food products. 
Table 6. Consumer evaluation of organic products

\begin{tabular}{|c|c|c|}
\hline The positive impact & Respondent & Percentage \\
\hline Become healthier & 102 & $74 \%$ \\
\hline No difference with non-organic products & 35 & $25 \%$ \\
\hline Feel more comfortable & 5 & $4 \%$ \\
\hline Total & 138 & \\
\hline
\end{tabular}

Based on respondents' experiences during the consumption of organic products and the perceived benefits as a result of the evaluation conducted, the future plans related to consumers' interest in organic products consumption are presented in Table 7.

Table 7. Consumption plans for organic products

\begin{tabular}{|c|c|c|}
\hline Consumption Plan & Respondent & Percentage \\
\hline Same as current & 63 & $46 \%$ \\
\hline Will try other organic products & 46 & $33 \%$ \\
\hline Will shift all of the other organic products & 29 & $21 \%$ \\
\hline Total & 138 & \\
\hline
\end{tabular}

$46 \%$ of respondents who already consumed organic products intended to maintain their consumption patterns as it was. This means that their consumption patterns do not increase or decrease, and they are also of no interest to try other organic food products. On the other hand, 33\% would try other organic products and $21 \%$ would switch all of the organic products they could find or buy in their usual everyday shopping needs.

\subsection{The Behavior of Non-organic Food Products' Consumer Communities}

It is interesting to note that there are people who were familiar with organic products but did not consume them and the reasons are described in Table 8. In general there are three groups of reasons why people do not consume organic products, although they are familiar with them. The three factors are prices, product availability and perception of quality problems or product benefit. Prices are relatively expensive, a fundamental problem, which were expressed by $70 \%$ of respondents. Product availability is an issue due to the fact that organic products are difficult to find; they were sold only in places experienced by $60 \%$ of respondents. Even $34 \%$ of respondents said that the products were not always available. A growing perception in the community about non- organic food products is the difficulty in differentiating them from non-organic products, as well as unclear benefits easily damaged products.
Table 8. Reason for not consuming

\begin{tabular}{|c|c|c|}
\hline Reasons & Respondent & Percentage \\
\hline More expensive & 33 & $70 \%$ \\
\hline Just sold a special place & 28 & $60 \%$ \\
\hline Products are not always available & 16 & $34 \%$ \\
\hline Difficult to distinguish with non-organic \\
products & 15 & $32 \%$ \\
\hline Perishable products (rapid expiration) & 11 & $23 \%$ \\
\hline The benefits are not clear & 8 & $17 \%$ \\
\hline Not interested to try & 3 & $6 \%$ \\
\hline Not have time to look for organic products & 1 & $2 \%$ \\
\hline Total & 47 & \\
\hline
\end{tabular}

Respondents who were not familiar with organic products were provided with an explanation of non-organic food products during the interview conducted. After that, the respondents were asked to consume their interest in organic products (Table 9). There were $7 \%$ of respondents who were not familiar with organic products; $50 \%$ were interested in consuming the products, while the other $50 \%$ were less to no interest. The reasons why they were not interested in consuming the products were, firstly, the prices were relatively expensive (53\%) and secondly, they doubted their benefits (47\%). As for respondents who were interested, $90 \%$ were grounded because the benefits were obvious.

Table 9. Consumption willingness for people who are not familiar with organic products

\begin{tabular}{|c|c|c|}
\hline Interest for those who are not familiar with & Respondent & Percentage \\
\hline Lack of interest & 1 & $7 \%$ \\
\hline Not interested & 3 & $21 \%$ \\
\hline Between interested and not & 3 & $21 \%$ \\
\hline Interested & 7 & $50 \%$ \\
\hline Total & 14 & \\
\hline
\end{tabular}

The high prices of these products are due to the costs of production, which are more expensive, so they may not be sold at prices equal to non-organizational products. Therefore, it is required to know the percentage of the overpriced rates of organic products that can still be accepted by consumers. This information is presented in Figure 4 below.

In Figure 4, the demand curve can be seen; generally, 5\% differences in prices is the price level that is considered reasonable by all consumers, while differences up to $10 \%$ in organic products will lead to demand by $80 \%$ more consumers. However, until the difference in prices of $20 \%$, organic products are still in demand by nearly $50 \%$ of the consumers. In fact, there are still about $20 \%$ of respondents that are still willing to buy organic food products up to $50 \%$ price differences. 


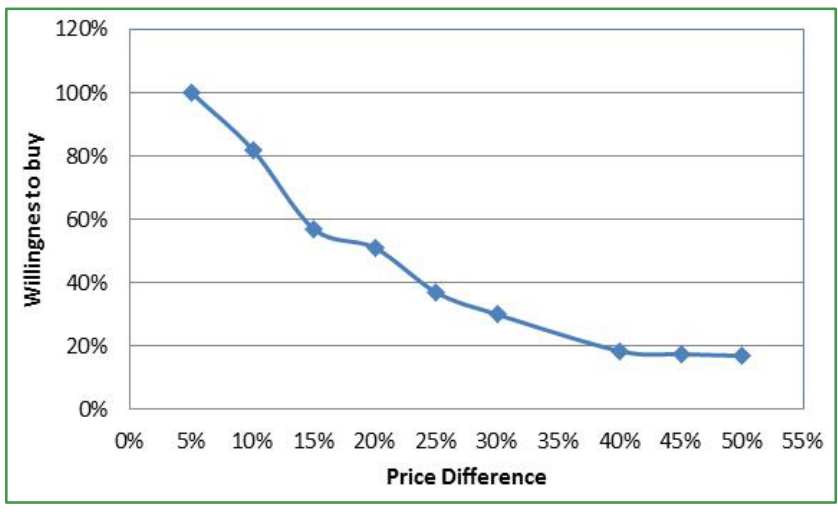

Figure 4. Overpriced rates of organic products that can still be acceptable to consumers

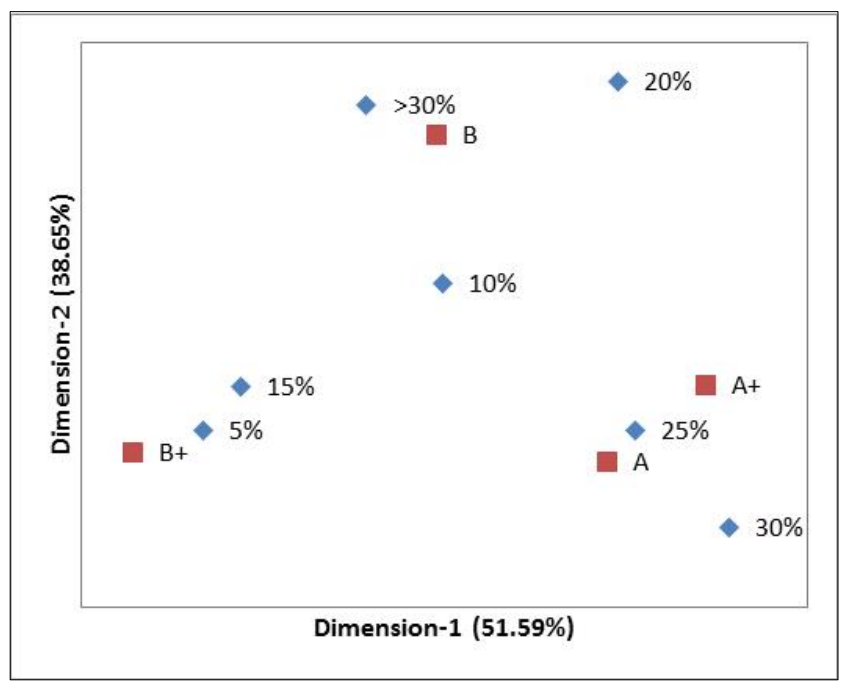

Figure 5. Association between the differences in prices with the SEC

The levels of interest associated with respondents who are affected by the levels of household expenditure are important information to know for sure one of the characteristics of potential markets for organic products. By using the Chi-Square analysis, which was then deepened with correspondence analysis, the information on these linkages is presented in Figure 5. It can be explained that the public's interest to buy organic products is associated with the differences in prices and has no linear association with the levels of their expenditure. It means that there is no consistent pattern to indicate that the larger the household expenditure is, the greater the acceptance of differences in prices is.

\section{Discussion}

Most of the upper middle class people are familiar with the economy of organic food products, but only $13 \%$ of those have been eating regularly, while others only eat occasionally. There are three organic food products commonly consumed daily, namely vegetables, fruits and rice. Keep in mind that rice is the staple food of the people of
Indonesia.

When associated with the demographic aspect, the SEC and the levels of education are the two main factors that are relevant to the consumption habits, where the consumers with A level of expenditure (SEC A+ or A) and relatively high education (graduate and post graduate) consume relatively a lot of these products. However, this does not mean that the higher the education level is, the higher the level of spending is. The main reasons put forward by those who consume organic foods are organic foods are healthy and more nutritious and taste better; in addition, the dominant perception of the consumer group that has consumed organic food products is that organic food products are free from chemicals that are harmful to health.

For those respondents who did not consume organic food products, there are three main reasons, i.e. prices, product availability and perception of benefit. Currently, the prices of organic products are more expensive, around $20 \%$ to $40 \%$ compared to the price of non-organic food products, Logically, it must be for the SEC A and SEC A+; the differences in prices are not the main reason for not taking them, because they can still afford them, but their doubts on the benefits of organic products have prevented them from consuming.

When traced further in the current group of non-consumption respondents, it is apparent that some of them did not feel the immediate benefits associated with health, even up to the perception that there were no differences between the benefits of organic and non-organic products; another problem felt by non-consumption respondents was product availability factor. It should be pointed out that, at the time of the survey, organic food products were sold in those places, where potential buyers usually shopped in these places. This is due to the limited supply of organic products, both in number and types; in addition, the products are more easily damaged. Conversely, non-organic products are cheaper, all types are available and can be obtained easily.

Related to the price issue, price differences up to $5 \%$ are considered the norm for most people, however $50 \%$ of consumers are still willing to consume these products to reach $20 \%$ price differences. Facts discovered have shown that there are still about $20 \%$ of people that willingly consume these products up to $40 \%$ price difference. This is consistent with the facts found today.

In economic theory, the high price of organic products should have motivated producers to increase supply, but this fact did not happen. This proves that the market for organic products is still limited. The abundant supply of needed storage space at the end will increase production costs. Efforts are taken to encourage people to willingly consume organic food products, not only based on price factor, but also based on the matter of perception. Therefore, a vigorous and purposeful communication about the benefits of product availability with a factor to be considered by the relevant parties is needed. On the other hand, an attempt to 
lower production costs, through government subsidization, is needed along with the lack of regulation for these products to be able to be mass produced.

\section{Conclusions}

High-expenditure group with a relatively high level of education is consistent in realizing their interest to consume organic products. Meanwhile, for people with lower-middle expenditure groups, their behavior in consuming organic products is only occasional. This is caused by the high price of organic products, hence consumers have not yet fully switched to organic products. Another problem that is quite crucial is that organic products are not always available continuously; as a result, people who wish to consume them on a regular basis cannot meet their needs.

From the aspect of prices, up to $10 \%$ differences between organic products and non-organic products can be accepted by all groups of people who are used to consume organic products. However, even though the price differences are up to $30 \%$, a group of people with high expenditure are still willing to buy organic foods. Groups of people who have already known about organic products but do not consume them argue that prices are still considered expensive, it is difficult to obtain the benefits of organic products and there are no differences between organic products and non-organic products. These communities generally come from lower middle economic class.

Age and sex do not distinguish their desire to consume or not consume organic products. This will be favorable aspects later in the campaign for healthy living programs by consuming organic products, because there will be no blocking from the main aspects of demography.

Mass production through subsidies and government regulations is needed so that producers can produce at an efficient scale in order to be able to push prices up at a level that is acceptable to consumers. On the other hand, continuous communication to build awareness and perception of the benefits of organic products associated with environmental sustainability needs to be done.

\section{Limitation}

Limitation of the study lies in the categories of samples used as the sources of information. Although most of them come from socio-economically middle class group, it does not reflect the condition of the entire population. Consideration is done when the prices of organic products are relatively expensive, thus only certain groups have the potential to consume them socio-economically. Therefore, effort to study the behavior of these groups is a priority. Future researches in accordance with that suggested by [28], especially in Indonesia, are needed; researches in organic products need to be linked with the socio-cultural aspects as well as the active role of local governments and the private sector in campaigning for healthy behavior.

\section{REFERENCES}

[1] Agresti, A. Categorical Data Analysis, 2nd ed., New York: Wiley, 2002.

[2] Ahmady, M., Sumarwan, U., Suharjo, B., Maulana, A., (2011), Relationship Marketing in Agricultural Products: Empirical Evidence from the Agricultural Sector in Western Region of Java.

[3] Ali, A, Khan, A.A., Ahmed, I (2011). Determinants of Pakistani Consumers' Green Purchase Behavior: Some Insights from a Developing Country. International Journal of Business and Social Science Vol. 2 No. 3 [Special Issue]. 217-226.

[4] Benzécri, J.P. Correspondence Analysis Handbook, New York: Marcel Dekker, 1992.

[5] Bhate, S. \& Lawle, K. (1997). Environmentally friendly products: factors that influence their adoption, Technovation, 17(8), 457-465.

[6] Bisnis Indonesia, 2004, Potensi Pasar Produk Organik di Indonesia, Vol 3.

[7] Bray, J., Johns, N., \& Kilburn, D. (2011). An exploratory study into the factors impeding ethical consumption. Journal of Business Ethics, 98(4), pp. 597-608

[8] Briones, A. (2000), 'Organic agriculture in Asia: Implications to development, environment and trade in developing countries.

[9] Central Bureau of Statistics Indonesia, 2015. Penduduk Indonesia menurut Provinsi 2010-2015.

[10] Chan, R.Y.K. \& Lau, L.B.Y. (2000), Antecedents of green purchases: A survey in china, Journal of Consumer Marketing, vol. 17 , pp. $338-357$.

[11] D’Souza, C., Taghian, M. \& Khosla, R. (2007). Examination of environmental beliefs and its impact on the influence of price, quality and demographic characteristics with respect to green purchase intention. Journal of Targeting, Measurement and Analysis for Marketing, 15(2), 69-78

[12] Follows, S. B. and Joober, D. (2000), Environmentally responsible purchase behavior: a test of a consumer model. European Journal of Marketing, vol. 34, pp. 723-746.

[13] Gan, C., H. Y. Wee, L. Ozanne \& T.H. Kao (2008), Consumer's Purchasing Behavior toward Green Products in New Zealand, Innovative Marketing Vol 4 Issue 1.

[14] Griffiths, J. (2010). Organic food and drink, Market Assessment 2010, Seventh Edition, Keynote.

[15] International Federation of Organic Agricultural Movement, (2008), www.ifoam.org

[16] Khorniawati, M (2014); Produk Pertanian Organik di Indonesia;Tinjauan atas Preferensi Konsumen Indonesia terhadap Produk Pertanian Organik Lokal, Jurnal Studi Manajemen, Vol 8, No 2., 171-182. 
[17] Krystallis, A. and Chryssohoidis, G. (2005), "Consumers' willingness to pay for organic food-factors that affect it and variation per organic product type", British Food Journal, Vol. 107 No. 5, pp. 320-43.

[18] Laroche, M., Bergeron, J. and Barbaro-Forleo, G. (2001), "Targeting consumers who are willing to pay more for environmentally friendly products", Journal of Consumer Marketing, Vol. 18 No. 6, pp. 503-20.

[19] Mohr, L. A., Webb, D. J., \& Harris, K. E. (2001). Do consumers expect companies to be socially responsible? The impact of corporate social responsibility on buying behavior. Journal of Consumer affairs, 35(1), 45-72

[20] Pickett-Baker, J., \& Ozaki, R. (2008). Pro-environmental products: marketing influence on consumer purchase decision. Journal of Consumer Marketing, 25 (5), 281-293.

[21] Sharma, Y. (2011), Changing Consumer Behaviour with Respect to Green Marketing- A case Study of Consumer Durables and Retailing. International Journal of Multidisciplinary Research, Vol 1 Issue 4.

[22] Sulaeman, A.(2007) Prospek Pasar dan Kiat Pemasaran Produk Organik. Bogor Institute of Agriculture. Susenas
(2010) BPS 2010.

[23] Vermeir, I., \& Verbeke, W. (2008). Sustainable food consumption among young adults in Belgium: Theory of planned behaviour and the role of confidence and values. Ecological Economics, 64(3), 542-553.

[24] Wandel, M. and Bugge, A. (1997), "Environmental concern in consumer evaluation of food quality", Food Quality and Preference, Vol. 8 No. 1, pp. 19-26.

[25] Widjajanto, D.W. and Miyauchi, N. (2002), Organic farming and its prospect in Indonesia. Bull. Fac. Agric. Kagoshima University, 52: 5762.

[26] Wilkins, J.L. and Hillers, V.N. (1994), "Influences of pesticide residue and environmental concerns on organic food preference among food cooperative members and non-members in Washington State", Journal of Nutrition Education, Vol. 26 No. 1, pp. 26-33.

[27] Winarno, F.G. (2009), Produk Organik Potensi dan Permasalahannya, IPB Press.

[28] Yatish, J and Zillur, R. (2015), Factors Affecting Green Purchase Behaviour and Future Research Directions. International strategic management review 3, pp. 128-143. 